\title{
SAICA’s ACADEMIC TRAINEESHIP PROGRAMme: WOULD GUIDELINES FACILITATE FOCUSED SKILLS DEVELOPMENT?
}

\author{
Petra Warffemius* \\ Stellenbosch University \\ petrawarffemius@yahoo.com \\ Lukas Kruger\# \\ Gretha Steenkamp+ \\ Stellenbosch University \\ Stellenbosch University \\ kruger.luk@gmail.com \\ gvn@sun.ac.za \\ Received: January 2014 \\ Accepted: November 2014
}

\begin{abstract}
The South African Institute of Chartered Accountants (SAICA) developed the Academic Traineeship Programme (ATP) to give trainee chartered accountants (CAs) the opportunity to complete one of their three training years in an academic environment. The structure and guidelines of the ATP should be reconsidered given changes in the overall CA (SA) Training Programme (e.g. increased focus on the development of the prescribed competencies, especially pervasive skills) and in the academic environment (e.g. increased emphasis on research). This article presents the findings of a study that surveyed current academic trainees and found that they spend most of their time on the presentation of tutorials, marking of assessments and student consultation. The surveyed academic trainees believe that stricter guidelines for how they spend their time would be beneficial; also, they would prefer to do more lecturing and research. Guidelines are proposed based on an inclusive stakeholder model and on SAICA's Competency Framework, which shows increased focus on research and the setting of assessments.
\end{abstract}

Keywords

Academic trainee, ATP (Academic Traineeship Programme), SAICA (South African Institute of Chartered Accountants), Pervasive skills, Competency Framework, CA 2010 Training Programme, Training guidelines

*Ms P Warffemius is a past honours' student in the School of Accountancy, Stellenbosch University, South Africa. "Mr L Kruger is a past honours' student in the School of Accountancy, Stellenbosch University, South Africa. +Mrs G Steenkamp is a senior lecturer in the School of Accountancy, Stellenbosch University, South Africa. 


\section{INTRODUCTION}

To become a member of the South African Institute of Chartered Accountants (SAICA), prospective members who successfully completed a Certificate in the Theory of Accounting (CTA) are required to enter into a three-year training contract with a registered training office. As a regulating body, SAICA determines the content of the training programme to be mastered before a prospective member may be allowed membership of SAICA. For the purposes of this article, a trainee is defined as a person who is employed by a SAICA-accredited training office and serves under a training contract.

SAICA introduced the Academic Traineeship Programme (ATP) to enable academically strong students to develop their technical skills in an academic environment with the aim of attracting them to an academic career. This effectively allows trainees to complete the first year of their three-year training contract with an accredited accountancy unit such as an accounting department or school at a university. The remainder of their training is completed (as normal) in public practice, commerce or the public sector. Trainees electing to follow this route are referred to as academic trainees. SAICA requires accountancy units to expose academic trainees to all the activities listed in the HOD/Supervisor's Report (SAICA, 2007) during the trainees' first year of training (SAICA, 2012c). These activities include but are not limited to lecturing, tutoring, preparing course material, grading assessments and conducting research - all to prepare academic trainees for embracing the role of future educators or academics, or both.

During 2010, SAICA implemented a revised training programme for academic as well as nonacademic trainees that seeks to align the training programme with the new Competency Framework. This Competency Framework contains a list of prescribed competencies required of entry-level South African chartered accountants (CAs (SA)) (Steenkamp, 2012). The Competency Framework shows increased emphasis on so-called pervasive skills (traditionally referred to as soft skills) and expands the skills set of CAs (SA) beyond the normal technical competencies (Steenkamp, 2012). According to Kleinhans (2008), SAICA's main reason for changing the training programme was to ensure that the designation "CA (SA)" remained relevant and valuable within the changing business and economic environment.

Given the above changes to SAICA's training programme, as well as changes in the academic environment (e.g. increased focus on research), certain areas of the ATP may need improvement. In addition, the academic activities listed in the HOD/Supervisor's Report do not necessarily contribute to developing the competencies prescribed in the Competency Framework. This may require guidelines that are more specific, e.g. how academic trainees should allocate their time with a view of achieving the prescribed competencies.

\section{RESEARCH QUESTIONS AND RESEARCH CONTRIBUTION}

\subsection{Research questions}

The following research questions were developed to enable a better understanding of the current ATP structure with a focus on skills development:

1. How much time do academic trainees spend on a particular academic activity, and are there significant discrepancies regarding how much time trainees employed at different accountancy units spend on any particular academic activity? 
2. Do academic trainees believe that SAICA should provide accountancy units with guidelines regarding exposure to academic activities or the minimum/maximum time to be spent on each academic activity?

3. If SAICA decides to provide guidelines on how academic trainees should spend their time, how would SAICA go about establishing such guidelines?

3.1 How much of their time would academic trainees prefer to spend on each academic activity?

3.2 Which academic activities contribute to the development of the competencies listed in the Competency Framework?

\subsection{Research contribution}

The data collected and interpreted in this study will benefit prospective academic trainees as well as their respective audit firms, universities and SAICA by provoking a detailed analysis of the current ATP and by providing a platform from which to direct change, if necessary.

\section{LITERATURE REVIEW}

A literature review was undertaken firstly to gain understanding of the changes to SAICA's training programme and to the academic environment, i.e. concerning the duties and skill required of entry level CAs (SA) and academics. Secondly, with these changes in mind, the ATP in the current academic environment was evaluated with reference to the existing regulations regarding academic trainees. Thirdly, the study relied on previous research regarding training programme development.

\subsection{Changes made to the CA training programme}

The training of prospective CAs (SA) has undergone significant changes over the past few years due to the development of the Competency Framework, which prescribes the competencies required of CAs (SA) upon qualification (Steenkamp, 2012). The compulsory competencies are "accounting \& external reporting" and "pervasive skills" (SAICA, undated). Pervasive skills have become increasingly important and encompass those skills that traditionally were referred to as soft skills (Steenkamp, 2012), for example the use of information technology, communication skills, knowledge of corporate governance, an ethical outlook and leadership skills (SAICA, 2012d). Additionally, trainee accountants need to develop an elective skills set (choosing between "auditing \& assurance", "financial management", "management decision-making \& control", "taxation" and "internal audit, risk management \& governance") as well as residual skills (SAICA, undated).

SAICA has developed two review forms for the purpose of evaluating trainee accountants - the Technical Skills Review (TSR) form and the Professional Skills Review (PSR) form. The PSR evaluates the extent to which a trainee accountant has developed pervasive skills in four areas, namely business ethics, management and leadership, personal attributes, and information technology (SAICA, 2012a). Trainees perform self-assessments of these competencies and provide evidence in support of their claimed level of competence, after which a reviewer adds feedback comments. The TSR was designed to evaluate the technical skills trainees should be able to perform upon completion of their training contract (SAICA, 2012b). These technical skills 
requirements have remained essentially unchanged with the introduction of the new 2010 Training Programme.

\subsection{The increased focus on research in the academic environment}

According to Van der Schyf (2008), the pressure on accounting departments with SAICA-accredited programmes is on the increase in that their predominant focus has long been directed at student training, often neglecting the academic objectives of research and scholarly activity, which represent the essence of a university. There are two reasons for the focus on teaching, namely the high expectations of SAICA and the need for accountancy units to retain their accreditation (Paliwal \& Beukes, 2011). Oza (2011) affirms that research is of great importance in the accounting education sphere, but that accounting departments have produced less research than other academic departments (Paliwal \& Beukes, 2011).

Historically, CAs (SA) were promoted to the position of senior lecturer not for academic reasons per se, but rather for remuneration purposes in order to motivate $C A s(S A)$ to move from practice to the academic environment (Paliwal \& Beukes, 2011). This did not encourage academic excellence in the field of research, which means that there is a definite need to sensitise academics to their role in research and publishing (Paliwal \& Beukes, 2011). Burke, Katz, Handy and Polimeni (2008) also emphasised the growing importance of research in the accounting profession in general. The profession is urging educators to focus on teaching critical-thinking and research-related skills (Albrecht \& Sack, 2000). As research-related skills are crucial to accountants today, teaching students how to develop these critical skills should be among the goals of accounting programmes (Burke et al., 2008).

\subsection{Evaluating the ATP within the context of the current academic environment}

SAICA lists two main objectives with creating the ATP:

- To relieve staffing shortages within accountancy units; and

- To ensure academic succession (SAICA, 2012c).

The above list may be incomplete, and further valid programme objectives might be identified by following an inclusive stakeholder approach. In light of changes in the accounting academic environment, it would seem that a need for research initiatives exists in accountancy units.

Keeping in mind the increased importance of research activities to an accounting academic department, the question arises whether the ATP could and should be used specifically to develop young potential accounting researchers. Current undergraduate and postgraduate accounting programmes at many universities include no research components worth mentioning. Since research methodology and related skills are not developed at student level, these qualities are lacking in both academic and non-academic trainees.

\subsection{Regulations currently applicable to the ATP}

Both academic and non-academic trainees who enter into a training contract with a registered training office are required to gain experience and achieve competence in all SAICA-prescribed competencies, while SAICA's training regulations require them to achieve the minimum number of core experience hours (SAICA, 2013). The year an academic trainee completes at an 
accountancy unit will be deemed the equivalent of one-third of the minimum core experience hours required.

Historically, the performance evaluation of academic trainees involves the completion of an HOD/Supervisor's Report every six months. There are two components to be completed, the first being the self-assessment by the academic trainee and the second the progress report by the supervisor. The self-assessment requires the trainee to allocate a percentage of exposure to each of the activities listed in the evaluation form, namely:

\section{Lecturing}

2. Tutorials

3. Preparation of teaching material

4. Setting and marking of assessments

5. Research

6. Preparation and study for Qualifying examination (now replaced by the Initial Test of Competence (ITC))

7. Student consultation

8. Other (SAICA, 2007).

Although items 6 and 7 above are not mentioned in the updated regulations issued in August 2013 (SAICA, 2013) as items to which academic trainees should be exposed, they do appear in the HOD/Supervisor's Report. Item 6 has become outdated, as the ITC is now written in January before most trainees commence their training contract; therefore, this item is disregarded for the purpose of this research article. Exposure is not defined in the HOD/Supervisor's Report and subsequently does little to regulate the amount of time academic trainees spend on any particular task, especially because "exposure" does not set a standard for measurement. Exposure is therefore interpreted according to the needs of the particular employer. On 21 May 2013, SAICA hosted a workshop for academic trainees in Johannesburg. It was evident from discussions at the workshop that an academic trainee's exposure to the tasks mentioned varied significantly according to their place of employment.

SAICA's rules regarding the ATP, as modified in August 2013, now also require the head of an accountancy unit to ensure that TSR and PSR forms are completed for each academic trainee (SAICA, 2013). Before, these forms were used only when the trainee joined a "normal" training office. Although, via the PSR and TSR, academic trainees will now be subject to the same evaluation as non-academic trainees, this is no guarantee that the tasks performed by academic trainees (as listed in the HOD/Supervisor's Report) are aligned to the Competency Framework or develop the competencies listed on the PSR and TSR review forms.

\subsection{The development of training programmes}

Ferguson (1998) states that guidelines relating to internship programmes improve consistency. To create an effective training programme, performance appraisal forms need to be evaluated, while the relevant stakeholders (e.g. participants and employers) also need to be considered (Kirkpatrick, 1994). An all-stakeholder approach that includes the perceptions of the trainees themselves is therefore important - when designing a training programme initially and when making programme changes (Ferguson, 1998). 


\section{RESEARCH METHODOLGY}

\subsection{Main research design}

The research design consists of two main components. The first component is related to research questions 1 and 2 (see section 2.1) and was aimed to gather primary data from current academic trainees. To accomplish this, a quantitative research design was chosen for conducting an empirical study using a custom-designed questionnaire. Further details are presented in section 4.2 .

Following on the findings of the first component, namely that academic trainees in general would prefer stricter guidelines for the ATP, the second component considered how these guidelines could be established or developed (research question 3 under section 2.1). The research design followed for this part of the research was a mixed method, which included:

Step 1: Evaluating the needs of all stakeholders in the ATP (identifying the stakeholders and considering their needs)

Step 2: Further considering the needs of the two main stakeholder groups, namely:

(a) The preferences of academic trainees regarding how they would spread their time between academic activities, using the same questionnaire employed in the first component of the research (refer to section 4.2); and

(b) The needs of SAICA and the profession with regard to the ATP (see section 4.3).

\subsection{Questionnaire presented to academic trainees}

A questionnaire was designed to gather primary data regarding the perceptions of academic trainees. The questionnaire consisted of four sections. The first section asked which university (accountancy unit) employed the specific trainee, to ascertain whether the sample was representative of all universities. The second section requested academic trainees to indicate how their time was divided between typical academic activities. Thirdly, the academic trainees were asked whether they would prefer stricter guidelines from SAICA regarding how their time as academic trainees should be spent. The last section asked academic trainees to indicate how they would prefer to divide their time between typical academic activities.

The typical academic activities mentioned in the questionnaire are based on the academic activities listed in the HOD/Supervisor's Report, which is used to evaluate the performance of the academic trainees. Although SAICA lists "marking and setting of assessments" as a single academic activity, it was decided to divide this activity into two sub-activities, namely "marking of assessments" and "setting of assessments" - as these two sub-activities are very different in nature and develop different skills. This also allowed for the collection of more specific and accurate data.

"Preparation of teaching material" was added to "lecturing", "tutoring" as well as "other". It was added to "lecturing" and "tutoring", as in many instances the preparation of material is an integrated part of preparing for lectures and tutorials. Adding it to "other" was for those instances when material needs to be prepared for other lecturers. "Administrative duties" was added as a separate category, based on practical experience of the amount of time academics have to spend on administration. TABLE 1 (refer to section 4.3.2) compares the academic activities in the HOD/Supervisor's Report and those in the questionnaires. 
A pilot survey was conducted by presenting the questionnaire to current lecturers who are former academic trainees. Ambiguous questions were modified and suggestions made by the pilot group were incorporated in the questionnaire design. A link to the final electronic questionnaire (which was set up using SUrveys - an electronic survey creation tool) was then sent to all academic trainees employed by SAICA-accredited universities during 2013. The number of trainees (81) and the contact details were gathered by contacting the relevant universities. The responses were logged using https://survey.sun.ac.za (Checkbox ${ }^{\circledR}$ v4.7) and evaluated using the STATISTICA program.

\subsection{Evaluating the needs of SAICA and the profession}

The needs of SAICA and the profession regarding the training of prospective CAs (SA), specifically academic trainees, were assumed to be contained in (a) the Competency Framework and CA 2010 Training Programme, summarised in the PSR and TSR evaluation reports used for all trainee accountants; and (b) the SAICA objectives of the ATP. The academic activities which academic trainees spend their time on therefore had to be mapped to the PSR and TSR evaluation reports and to the ATP objectives in order to evaluate to what extent these activities develop the competencies required of a qualified CA (SA) participating in the ATP. This was to enable an understanding of which academic activities are most important in developing the required competencies and how academic trainees should be guided to spend their time.

\subsubsection{The population}

To map the academic activities to SAICA's competencies and the ATP objectives, persons knowledgeable in both had to be surveyed, as the opinion of one person would not suffice. CAs (SA) who lecture at CTA (Certificate of Theory in Accounting) level were identified as persons who had the required knowledge and experience in that they were academics themselves and would be familiar with the academic activities. Moreover, they train students at the highest level based on academic programmes informed by the Competency Framework.

All CTA lecturers in South Africa, or a sub-group of them, could be targeted for the survey. It was deemed more important to obtain a balanced view among lecturers teaching the different subjects offered in an academic programme (i.e. traditionally financial accounting, management accounting, auditing, and taxation) than surveying all lecturers in the country. Academic activities and the way they develop competencies were not expected to differ widely among the various provinces. As the different subjects develop pervasive skills differently, a balanced view from the subjects was considered important. Ethics, for example, plays a much more important role in auditing than in other subjects.

Therefore, it was decided to aim for a $100 \%$ response rate from the CTA lecturers at one university. For ease of access and for gathering the 100\% response rate, Stellenbosch University's CTA lecturers were selected for the study. A second questionnaire, aimed at determining how the academic activities relate to the PSR and TSR competencies, was presented to the 12 CTA lecturers at Stellenbosch University. The eventual response rate was $100 \%$.

\subsubsection{Questionnaire design}

Based on the HOD/Supervisor's Report, the questionnaire was designed by listing the academic activities in columns, while the desired outcomes of the ATP (i.e. the competencies in the PSR and TSR evaluation reports and the SAICA objectives of the ATP) were listed in rows. The CTA 
lecturers were required to indicate, using a number from 0 to 4 , to what extent the activities listed in the HOD/Supervisor's Report contributed to the development of the competencies required by the PSR and TSR, as well as the SAICA objectives of the ATP. A response of 0 represented no development, while 4 represented very good development.

The academic activities in the HOD/Supervisor's Report were evaluated to determine if any of them were similar in nature and would therefore be expected to develop similar competencies. For this reason, "lecturing", "tutorials" and "preparation of teaching material" were combined. In addition, "setting and marking of assessments" in the HOD/Supervisor's Report was again divided into two separate academic activities because setting and marking develop skills in a different manner, and to ensure comparability and consistency with the first questionnaire. "Administrative duties" and "other" were also combined into "other admin", because "other" is not defined and therefore could not be mapped separately to specific skills. TABLE l presents the final six academic activities that were added as columns in the questionnaire.

\section{TABLE 1: Comparison of academic activities}

\begin{tabular}{lll}
\hline $\begin{array}{c}\text { Activities in HOD/ } \\
\text { Supervisor's Report }\end{array}$ & $\begin{array}{c}\text { Academic activities in } \\
\text { (uestionnaire 1 } \\
\text { (Academic trainees) }\end{array}$ & $\begin{array}{c}\text { Academic activities in } \\
\text { Questionnaire 2 } \\
\text { (Lecturers) }\end{array}$ \\
\hline Lecturing & $\begin{array}{l}\text { Lecturing (including preparation } \\
\text { for lectures) }\end{array}$ & $\begin{array}{c}\text { Lecturing, Tutorials and } \\
\text { Preparation of material }\end{array}$ \\
\hline Tutorials & $\begin{array}{l}\text { Tutorials (including preparation } \\
\text { for tutorials) }\end{array}$ & \\
\hline Preparation of teaching material & - & Setting assessments \\
\hline Setting and marking of & Setting assessments & Marking assessments \\
Ressearch & Marking assessments & Research and/or further study \\
\hline Student consultation & Research & Student consultation \\
\hline Other & Student consultation & Other admin \\
\hline
\end{tabular}

Source: Authors' analysis

The desired outcomes of the ATP (added as rows in the questionnaire) were listed as follows:

A. Professional skills developed:

The skills were a duplication of those contained in the PSR.

B. Technical skills developed:

The TSR was consolidated to represent a single line in the questionnaire, namely "The development of technical skills". The reason for this was that many academic trainees are assigned to specific subjects during the ATP and would only gain skills in that specific technical field. 
C. Objectives of the ATP:

The two objectives as defined by SAICA were used, i.e. attracting future academics and relieving staff shortages.

The activity/activities that contributes/contribute most to achieving the desired outcomes of the ATP should be seen as the most important when a specific accountancy unit or SAICA considers the structure of the ATP. The relative importance of the activities can also be used as a guideline for evaluating current ATP structures.

\section{RESULTS OF THE QUESTIONNAIRE PRESENTED TO ACADEMIC TRAINEES}

A total of 81,2013 academic trainees were requested to participate within this study. 47 responded, yielding a response rate of $58 \%$. Listed in TABLE 2 below is an analysis of the response rate per accountancy unit. No accountancy unit accounts for more than a third of the responses, indicating that the data gathered is unbiased. Most of the accountancy units had an internal response rate of $50 \%$ or higher, except Nelson Mandela Metropolitan University (NMMU) ( $0 \%$, but the university employs only one academic trainee), the University of Cape Town (UCT) (33\%) and the University of Pretoria (UP) (46\%).

TABLE 2: Response analysis

\begin{tabular}{|c|c|c|c|}
\hline Accountancy unit & $\begin{array}{c}\text { Number of } \\
\text { ATs } \\
\text { employed }\end{array}$ & $\begin{array}{l}\text { Number of } \\
\text { responses }\end{array}$ & $\begin{array}{c}\text { Percentage } \\
\text { of total } \\
\text { responses }\end{array}$ \\
\hline Nelson Mandela Metropolitan University (NMMU) & 1 & 0 & $0 \%$ \\
\hline North-West University (NWU) & 6 & 3 & $6 \%$ \\
\hline University of Johannesburg (UJ) & 16 & 12 & $26 \%$ \\
\hline University of the Witwatersrand (WITS) & 20 & 12 & $26 \%$ \\
\hline University of the Western Cape (UWC) & 2 & 2 & $4 \%$ \\
\hline University of Pretoria (UP) & 13 & 6 & $13 \%$ \\
\hline University of the Free State (UFS) & 4 & 3 & $6 \%$ \\
\hline University of Cape Town (UCT) & 15 & 5 & $11 \%$ \\
\hline University of Fort Hare & 1 & 1 & $2 \%$ \\
\hline University of Kwazulu-Natal (UKZN) & 1 & 1 & $2 \%$ \\
\hline Stellenbosch University (SU) & 2 & 2 & $4 \%$ \\
\hline Total & 81 & 47 & $100 \%$ \\
\hline
\end{tabular}

Source: Authors' analysis

\subsection{Research question 1: How are academic trainees currently spending their time?}

TABLE 3 shows the time allocated by 2013 academic trainees to each academic activity (measured as percentage of total time spent). The number of students attending both lectures 
and tutorials was defined (lecturing in case of 40 or more students, tutorials in case of fewer than 40 students) to gather more accurate data. Student consultation was also defined as fewer than five students, for the same reason.

TABLE 3: Actual time spent on academic activities (percentage of total time)

\begin{tabular}{lcccc}
\hline \multicolumn{1}{c}{ Activity } & Min & Max & Mean & $\begin{array}{l}\text { Standard } \\
\text { deviation }\end{array}$ \\
\hline $\begin{array}{l}\text { Lecturing }(>=40 \text { students, including preparation for } \\
\text { lectures) }\end{array}$ & 0 & 50 & 9.3 & 8.9 \\
$\begin{array}{l}\text { Tutorials }(<40 \text { students, including preparation for } \\
\text { tutorials) }\end{array}$ & 0 & 50 & 22.4 & 14.3 \\
$\begin{array}{l}\text { Student consultation }(<5 \text { students) } \\
\text { Setting of assessments }\end{array}$ & 5 & 50 & 17.6 & 9.5 \\
$\begin{array}{l}\text { Marking of assessments } \\
\text { Research }\end{array}$ & 0 & 30 & 7.0 & 5.1 \\
\hline Administrative duties & 5 & 55 & 21.1 & 11.8 \\
\hline Other (such as preparation of teaching material) & 0 & 35 & 6.9 & 6.8 \\
\hline
\end{tabular}

Source: Authors' analysis

Academic trainees seem to spend most of their time on teaching tutorials (mean of $22.4 \%$ ), marking assessments (21.1\%) and student consultation (17.6\%). The range of observations and the standard deviation could be useful in identifying activities where stricter guidelines might be beneficial to the trainee, i.e. where certain trainees might be over or underexposed to certain academic activities. Moreover, where a certain trainee has $0 \%$ exposure to one of the academic activities indicated above, this might lead to non-compliance with SAICA's regulations regarding the ATP, because the SAICA regulations require accountancy units to expose academic trainees to all the activities listed above. SAICA views the setting and marking of assessments as one activity, while student consultation is no longer a separate requirement in the updated Regulations.

The largest standard deviation is observed for "Tutorials" (14.3) and "Marking of assessments" (11.8). The biggest range differences are observed at "Lecturing" (50\%), "Tutorials" (50\%) and "Marking of assessments" (50\%). Depending on the skills developed by these activities, guidelines such as minimum and maximum exposure requirements could be useful to regulate the exposure to these activities.

The average time spent on research is $6.9 \%$. This may not be sufficient for the development of research skills in candidates who could return to the academic environment to pursue an academic career. From the literature study it is clear that research, or rather the lack of research, is a cause for concern in the accounting profession. Time spent on administrative duties seems to be reasonable: $10.1 \%$. It would appear that academic trainees are indeed used for proper academic purposes, and not only as administrative clerks. However, the maximum exposure of $35 \%$ is worrying. Individuals engaged in such a programme could be disadvantaged and potentially discouraged from following an academic career. 
It is clear that there are vast differences in the exposure that academic trainees receive while participating in the ATP. Because these activities are very different in nature, some trainees could be either over- or under-developing certain skills. The skill set that an academic trainee can hope to develop is therefore determined by the particular needs of the accountancy unit where they are employed (which is influenced by accountancy unit preferences and/or structure). Some universities may use academic trainees to present tutorials because tutorials form an important part of that specific accountancy unit's teaching philosophy, while academic trainees at other units may be required to do more marking and/or teaching of larger classes.

\subsection{Research question 2: Do academic trainees believe SAICA should develop guidelines?}

As is evident from TABLE 4, academic trainees believe, or believe to some extent, that stricter guidelines on how they should spend their time between academic activities would be beneficial. Most academic trainees agree, or agree to some extent, that SAICA should develop guidelines and that these would improve the ATP.

\section{TABLE 4: Guidelines in the ATP}

\begin{tabular}{|c|c|c|c|c|c|}
\hline & Agree & $\begin{array}{c}\text { Agree } \\
\text { somewhat }\end{array}$ & Neutral & $\begin{array}{l}\text { Disagree } \\
\text { somewhat }\end{array}$ & Disagree \\
\hline $\begin{array}{l}\text { Should SAICA impose } \\
\text { guidelines in the ATP to } \\
\text { regulate academic trainees' } \\
\text { exposure to the tasks listed in } \\
\text { the HOD/Supervisor's Report? }\end{array}$ & $26 \%$ & $45 \%$ & $11 \%$ & $6 \%$ & $13 \%$ \\
\hline $\begin{array}{l}\text { Guidelines will direct } \\
\text { attention to the management } \\
\text { of trainees' expectations and } \\
\text { improve the ATP }\end{array}$ & $45 \%$ & $34 \%$ & $11 \%$ & $9 \%$ & $2 \%$ \\
\hline
\end{tabular}

Source: Authors' analysis

\section{RESEARCH PUESTION 3: DEVELOPING GUIDELINES FOR THE ATP}

\subsection{All stakeholder approach}

If guidelines are to be developed, they should include input from all the relevant stakeholders. A list of potential stakeholders to the ATP was drawn up, and their needs regarding the ATP evaluated as follows:

0 University

- Flexibility: To ensure employability in the university structures

- Value adding: To ensure academic trainees are contributing towards the objectives of the university, e.g. research and education 
O Academic trainee

- Focused on the individual's skills development: To ensure that the ATP remains attractive and rewarding to those who choose to enrol in the programme; offering the individual opportunities for further development, with specific emphasis on academic development (further study, mentoring, research skills development, etc.)

- Keeping up with non-academic trainees' career development: To ensure that ATs can sign off on certain competencies set out in the PSR and TSR

o Prospective audit firm

- Preparation for practice: To ensure that audit firms benefit from allowing participation in the ATP (human capital is one of the key drivers of future value to companies, and the ATP should be a valuable asset that contributes experience and skills when the trainee joins a firm)

O SAICA

- Enforceable: To ensure SAICA can regulate the programme in a practical way

- Effective in meeting objectives of the program: To ensure that the current ATP objectives can be met, i.e. to train future academics and to address the shortage of accounting staff

- Effective in developing skills required of all trainees: To ensure that academic trainees can sign off on competencies as set out in the PSR and TSR.

\subsection{How academic trainees would like to spend their time}

When asked how they would like to spend their time, academic trainees responded as indicated in TABLE 5 (each activity measured as percentage of total time). Academic trainees showed a preference for "lecturing", "tutorials", "student consultation" (may be summarised as working directly with students) and "research" activities.

When TABLE 3 (actual time spent on academic activities) is compared to TABLE 5 (how academic trainees would prefer to divide their time between academic activities), the biggest expectation gap, based on the absolute change in mean time, is observed in "marking of assessments", "lecturing", "research" and "administrative duties". 
TABL 5: Ideal time spent on academic activities (percentage of total time)

\begin{tabular}{lcccc}
\hline \multicolumn{1}{c}{ Activity } & Min & Max & Mean & $\begin{array}{l}\text { Standard } \\
\text { deviation }\end{array}$ \\
\hline $\begin{array}{l}\text { Lecturing }>=40 \text { students, including preparation for } \\
\text { lectures) }\end{array}$ & 3 & 70 & 18.8 & 11.6 \\
$\begin{array}{l}\text { Tutorials (<40 students, including preparation for } \\
\text { tutorials) }\end{array}$ & 0 & 50 & 22.2 & 12.4 \\
$\begin{array}{l}\text { Student consultation (<5 students) } \\
\text { Setting of assessments }\end{array}$ & 5 & 50 & 18.6 & 9.6 \\
$\begin{array}{l}\text { Marking of assessments } \\
\text { Research }\end{array}$ & 0 & 20 & 9.5 & 5.6 \\
\hline Administrative duties & 0 & 30 & 9.8 & 6.7 \\
\hline Other (such as preparation of teaching material) & 0 & 50 & 12.0 & 9.7 \\
\hline
\end{tabular}

Source: Authors' analysis

Academic trainees would like to spend $11.3 \%$ less of their time on the marking of assessments, $9.5 \%$ more time on lecturing, $5.1 \%$ more time on conducting research and $5.3 \%$ less time on administrative duties. This comparison can be clearly seen in TABLE 6 .

TABLE 6: Comparison between actual time and ideal time spent on academic activities (percentage of total time)

\begin{tabular}{llc}
\hline \multicolumn{1}{c}{ Activity } & Actual & Ideal \\
\hline Lecturing ( $>=40$ students, including preparation for lectures) & $9.3 \%$ & $18.8 \%$ \\
Tutorials ( $<40$ students, including preparation for tutorials) & $22.4 \%$ & $22.2 \%$ \\
Student consultation ( $<5$ students) & $17.6 \%$ & $18.6 \%$ \\
Setting of assessments & $7.0 \%$ & $9.5 \%$ \\
Marking of assessments & $21.1 \%$ & $9.8 \%$ \\
Research & $6.9 \%$ & $12.0 \%$ \\
Administrative duties & $10.1 \%$ & $4.8 \%$ \\
Other (such as preparation of teaching material) & $5.7 \%$ & $4.2 \%$ \\
\hline
\end{tabular}

Source: Authors' analysis

\subsection{Developing guidelines based on skills development requirement set by SAICA Competency Framework}

Lecturers at Stellenbosch University were asked to map academic activities to which academic trainees should be exposed, as indicated in the HOD/Supervisor's Report, to the desired outcomes of the ATP. The desired outcomes were divided into three measures, namely:

(a) The professional skills to be developed by trainees as listed in the PSR 
(b) The technical skills to be developed (based on the TSR, but merged into one line in the questionnaire)

(c) The objectives of the ATP (according to SAICA).

Using a Likert scale of 0 to 4 , lecturers had to indicate the extent to which each activity developed the specific desired outcome or measure. The total score for each activity was determined separately for each measure. This total score was then expressed as a percentage of the total scores of all activities for a specific measure. The response reflects the importance of the specific activity in comparison to the other activities found in the ATP as regards developing the specific measure or desired outcome of the ATP. The results are presented in the first four rows of TABLE 7.

TABLE 7: Three-dimensional guideline measure

\begin{tabular}{|c|c|c|c|c|c|c|c|}
\hline \multirow{5}{*}{ 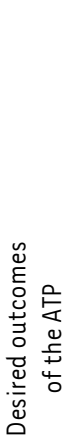 } & \multirow[b]{3}{*}{$\begin{array}{l}\text { Professional skills } \\
\text { development (PSR) }\end{array}$} & \multicolumn{6}{|c|}{ Activities performed by academic trainees } \\
\hline & & $\begin{array}{l}\text { Lectu- } \\
\text { ring and } \\
\text { Tutorials }\end{array}$ & $\begin{array}{c}\text { Research } \\
\text { and/or } \\
\text { further } \\
\text { study }\end{array}$ & $\begin{array}{l}\text { Setting } \\
\text { of } \\
\text { assess- } \\
\text { ments }\end{array}$ & $\begin{array}{c}\text { Marking } \\
\text { of } \\
\text { assess- } \\
\text { ments }\end{array}$ & $\begin{array}{l}\text { Student } \\
\text { consul- } \\
\text { tation }\end{array}$ & $\begin{array}{l}\text { Other } \\
\text { admin }\end{array}$ \\
\hline & & $20.2 \%$ & $20.8 \%$ & $17.5 \%$ & $13.4 \%$ & $15.8 \%$ & $12.4 \%$ \\
\hline & $\begin{array}{l}\text { Technical skills } \\
\text { development (TSR) }\end{array}$ & $21.3 \%$ & $20.3 \%$ & $19.3 \%$ & $13.7 \%$ & $20.3 \%$ & $5.1 \%$ \\
\hline & Objectives of the ATP & $20.8 \%$ & $13.2 \%$ & $15.4 \%$ & $15.1 \%$ & $23.0 \%$ & $12.6 \%$ \\
\hline \multirow{4}{*}{ 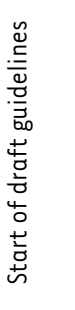 } & $\begin{array}{l}\text { Average time to be } \\
\text { spent }\end{array}$ & $21.0 \%$ & $18.0 \%$ & $17.0 \%$ & $14.0 \%$ & $20.0 \%$ & $10.0 \%$ \\
\hline & $\begin{array}{l}\text { Maximum time to be } \\
\text { spent }\end{array}$ & $21.3 \%$ & $20.8 \%$ & $19.3 \%$ & $15.1 \%$ & $23.0 \%$ & $12.6 \%$ \\
\hline & $\begin{array}{l}\text { Minimum time to be } \\
\text { spent }\end{array}$ & $20.2 \%$ & $13.2 \%$ & $15.4 \%$ & $13.4 \%$ & $15.8 \%$ & $5.1 \%$ \\
\hline & Flexibility & $1.2 \%$ & $7.6 \%$ & $3.9 \%$ & $1.7 \%$ & $7.2 \%$ & $7.5 \%$ \\
\hline
\end{tabular}

Source: Authors' analysis

The percentage assigned to each activity may be interpreted as follows: The activity with the highest percentage can be said to develop the most skills in the specific measure in which it has been evaluated, e.g. professional skills, technical skills or objectives. It is crucial that academic trainees be exposed to these activities for focussed skills development and reaching programme objectives.

The last four rows of TABLE 7 were used to start drafting guidelines. The average time to be spent was calculated as the average time between the three measures at the top of the table, i.e. "professional skills development", "technical skills development" and "objectives of the ATP". "Minimum time to be spent" and "Maximum time to be spent" were based on the smallest and largest of the three measures respectively. "Flexibility" shows the range between the minimum time and the maximum time. The results in TABLE 7 suggest that all three measures agree on how much time should be spent on each of the activities, with only $0.5 \%$ to $7.3 \%$ flexibility between 
the minimum and maximum value of the three measures, on all activities. The fact that the three measures are in relative agreement increases the reliability of the proposed guidelines and therefore gives an accurate picture of the activities that should form the core of the ATP.

Based on the above measures and the way academic activities are mapped to them, guidelines could be developed that would best meet the desired ATP outcomes. The three measures concerned create a focused approach for evaluating the current ATP and making recommendations on its future structure. One solution, which would provide flexibility and enhance employability from the perspective of accountancy units, is to create an ideal programme structure using the average percentage time to be spent on each of the academic activities indicated in TABLE 7 and allow a maximum deviation rate of $5 \%$ from the proposed ideal structure in each activity.

Another way to establish guidelines is to require accountancy units to ensure that the time academic trainees allocate to each activity ranges between the minimum and maximum percentages indicated in TABLE 7. In order to compare such proposed guidelines developed from the minimum and maximum percentages in TABLE 7 to the current programme structure presented in TABLE 3, these three were plotted against each other in FIGURE 1 . The range between the minimum and maximum time to be spent (flexibility) from TABLE 7 is shown as blocks representing the allowed range.

In general, the current programme seems to be misaligned with the proposed guidelines, as only "student consultation" falls into the flexibility range. One possible reason for this is that, currently, each accountancy unit structures the ATP to suit its own needs, thus the current programme would mostly represent employers' needs. The guidelines, however, aim to represent all stakeholders: the trainee, the accountancy unit, the audit firm and SAICA. The current ATP appears to overexpose academic trainees to the activities of "lecturing" (and "tutorials"), "marking of assessments" and "administrative duties" while underexposing them to the activities of "research" and "setting of assessments". Therefore, certain skills are being overdeveloped while others are being underdeveloped, leading to certain objectives being achieved while others are not.

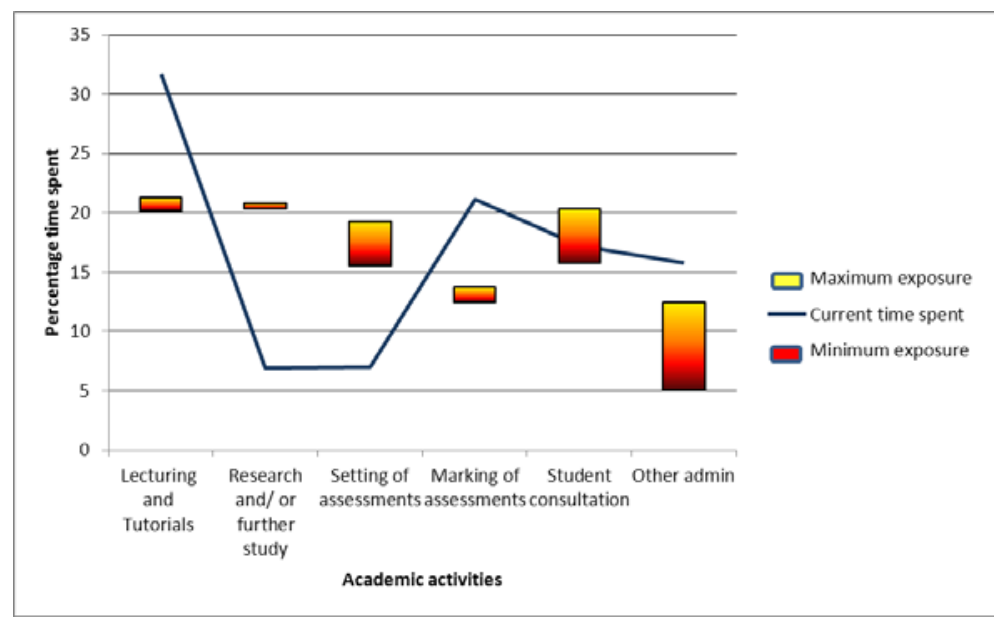

FIGURE 1: Plotting the current ATP structure to the proposed guidelines

Source: Authors' analysis 


\section{CONCLUSION AND RECOMMENDATIONS}

\subsection{Conclusion}

Currently, the academic activities that take up most of academic trainees' time are "lecturing", "tutorials", "marking of assessments" and "student consultation". Together, they account for more than $60 \%$ of trainees' time spent. There are, however, considerable discrepancies in the ways in which academic trainees are employed (possibly due to the individual accountancy unit's needs and preferences), which could explain the differences in skills development and trainees' job satisfaction. The academic activities where the biggest discrepancies were noted are "tutoring" and "marking of assessments". Most academic trainees agreed, or agreed to some extent, that SAICA should develop guidelines for the regulation of academic trainees' exposure to the various activities.

Academic trainees would prefer to spend more time on lecturing and research, which may be regarded as the key performance areas of academics. The need for accounting academic research has increased significantly over the past decade. This indicates an area in which accountancy units should endeavour to meet academic trainees' expectations and increase exposure. "Marking assessments" and performing "administrative tasks" were activities that academic trainees would prefer to spend less time on where possible.

Developing proposed guidelines on academic trainees' exposure to academic activities called for an all-stakeholder approach that evaluated the needs of trainees, of SAICA and of the various accountancy units. A multi-dimensional mapping was done, based on the various skills that had to be developed under a training contract in order to meet accountancy unit and trainee needs and to realise the ATP objectives as set by SAICA. This led to a draft guideline on the minimum and maximum amount of time to be spent on each academic activity. The most important activities proved to be "lecturing", "tutoring" and "research", followed by "setting assessments" and "student consultation".

By the nature of their exposure to tasks such as lecturing, tutoring and research, academic trainees should be better equipped to assume the position of lecturer and researcher when their three-year training period ends. The skills that academic trainees are required to obtain and develop within the ATP need to be meticulously defined in order to create a standardised skills set. This may be achieved by setting hour-based requirements instead of the broadly defined "exposure" to areas and skills listed in SAICA's HOD/Supervisor's Report.

\subsection{Recommendations}

Firstly, accountancy units need to take into account trainee preferences and expectations by endeavouring to increase trainees' exposure to the main academic activities of "lecturing" and "research". Research is especially important in the current academic environment, which means increased exposure would better equip an academic trainee for an academic career. For example, guidelines could make it compulsory for all academic trainees to write a scholarly article under the tutelage of an experienced researcher.

Secondly, SAICA should develop guidelines on how academic trainees should spend their time, and accountancy units should implement such guidelines. This would ensure skills development in line with the Competency Framework and the objectives of the ATP, namely to develop future academics. The proposed guidelines could take the form of an ideal programme structure, 
ensuring flexibility by allowing accountancy units a measure of deviation from the ideal structure. A further possibility would be to introduce guidelines on minimum and maximum exposure regarding time spent on each academic activity. This article suggests a methodology for developing such guidelines and calls for research and setting of assessments to be identified as areas that should receive more attention, while the marking of assessments as well as administrative duties could be areas that require downscaling.

\section{LIST OF REFERENCES}

Albrecht, W.S. \& Sack, R.J. (2000). Accounting education: Charting the course through a perilous future. Sarasota, FL: The American Accounting Association.

Burke, J.A., Katz R., Handy, S.A. \& Polimeni, R.S. (2008). Research skills: A fundamental asset for accountants. The CPA Journal, 78(1), pp. 66-69.

Harish, S.0. (2011). Accounting education and changing environment. Indian Journal of Accounting, XLII(1), pp. 1-2.

Ferguson, L.H. (1998). Guidelines for a safety internship program in industry. Professional Safety, 43(4), pp. 22-25.

Kirkpatrick, L. (1994). Evaluating training programs: The four levels. San Francisco: Berrett-Koehler Publishers.

Kleinhans, A. (2008). Changing the chartered accountancy professions'lanes - A revolutionary new training model. Available:

http://www.accountancysa.org.za/resources/PrintltemArticle.asp?Articleld =1578\&lssue=1069\&Load Frames $=N_{\underline{.}}$ (Accessed 29 October 2013).

Paliwal U.L and Beukes E.D. (2011). Accounting education and research in Southern Africa. Indian Journal of Accounting, XLII(1), pp. 3-5.

SAICA (South African Institute of Chartered Accountants). (2007). Academic trainee:

HOD/Supervisors report. Available:

https://www.saica.co.za/Portals/0/Trainees/documents/AcademicTraineeAssess.pdf. (Accessed 28 October 2013).

SAICA. (Undated). Summary of the structure and content of the CA(SA) training programme. Available:

https://www.saica.co.za/Portals/0/Trainees/documents/Structure\%20of\%20the\%20CASA\%20Trainin g\%20Programme.pdf. (Accessed 28 0ctober 2013).

SAICA. (2012a). Professional Skills Review template. Available:

https://www.saica.co.za/Training/Training/AssessmentofTrainees/tabid/420/language/enUS/Default.aspx. (Accessed 280 ctober 2013).

SAICA. (2012b). Technical skills review template. Available:

https://www.saica.co.za/Training/Training/AssessmentofTrainees/tabid/420/language/enUS/Default.aspx. (Accessed 280 october 2013).

SAICA. (2012c). Rules for the Academic Traineeship Programme. Available: https://www.saica.co.za/Portals/0/Trainees/Training/Pages\%2030to32\%20Training\%20regulations. pdf. (Accessed 28 0ctober 2013). 
SAICA. (2012d). CA(SA) Training programme: Prescribed competencies. Available:

https://www.saica.co.za/Portals/0/Trainees/documents/CA\%20SA\%20Training\%20Programme\%20C ompetencies\%20August\%202012.pdf. (Accessed 28 0ctober 2013).

SAICA. (2013). Training regulations (effective I January 2013). Available:

https://www.saica.co.za/Portals/0/Trainees/documents/CA2010\%20Training\%20Regulations.pdf. (Accessed 28 October 2013).

Steenkamp, G. (2012). Student perceptions regarding the new training programme for chartered accountants. Journal of Economic and Financial Sciences, pp. 485-502.

Van der Schyf, D.B. (2008). The essence of a university and scholarly activity in accounting, with reference to a Department of Accounting at a Southern African university. Meditari Accountancy Research, 16(1), pp. 1-2 